\title{
脳性麻痺児を対象とした歩行器の開発 ${ }^{1}$
}

西川康博2, 大島浩幸 ${ }^{2}$, 新田 收 ${ }^{3}$

\begin{abstract}
This study developed a new walker with improved operability for 3-9-year-old children with cerebral palsy (Gross Motor Function Classification System level III) and verified its validity. Although numerous walkers are available, their operability is suboptimal. The proposed six-wheel walker was classified as a posterior walker. To verify its validity, we selected three tasks that are frequently performed during daily activities: walking straight on a flat surface, walking up and down a step like the curb on the street, and turning left and right at a right angle. Five children were included, and they performed the three tasks using the proposed walker and a Posture Control Walker (PCW), which is the most commonly used commercial walker. Time to walk a 5-m distance in the middle of each task was measured. Our results revealed that the walking time with the proposed walker in the step task in three children and in the turn task in four children was shortened because of the improved operability by a series of actions that required lifting only the front wheels to turn our whole walker. These results suggest that the proposed walker is easier to operate and more effective in assisting walking than PCW.
\end{abstract}

本研究では，小児用歩行器の操作性の改善を目的とした。年齢が3歳から9歳程度で，主にGross Motor Function Classification Systemレベル IIIの脳性麻痺児を対象とした歩行器を開発した. 6輪を有す る開発歩行器は後方型歩行器に分類される。実証実験では，直線歩行路，段差歩行路，2種類の方向転 換歩行路を設定した．5名の脳性麻痺児（男児3名，女児2名）を対象として，開発歩行器と市販歩行器の 1つであるPosture Control Walker (PCW) を用いた，各歩行路の中央 $5 \mathrm{~m}$ 区間における歩行所要時間を 計測した，穴の結果，PCWと比較して開発歩行器を使用した場合，ハンドルを引き上げて前輪のみを浮 上させ，車体を旋回させるという一連の操作により，段差乗り越えでは3児，および，方向転換では4児 の歩行所要時間が短縮した。これにより，開発歩行器はPCWより優位な操作機能を有している可能性が 示唆された。

(キーワード：小児，脳性麻痺，歩行器，GMFCS，実証実験)

\section{1.はじめに}

脳性麻痺等の疾患により, 歩行が困難となった小児に 処方される移動支援機器の 1 つに歩行器がある. 海外に おいては, 杖や車椅子同様, 街中で日常的に歩行器を利 用する小児の姿を見ることができる，歩行器に関する研 究も積極的に行われており，例えばLynneら ${ }^{1)}$ は，7人の 脳性麻痺児と 1 人のダウン症児について前方型歩行器と 後方型歩行器を利用した際の特徵を比較し, 後方型歩行 器を利用する方が姿勢および歩行特性が改善することを 報告している. Eisenberg ら²) は, 自力移動が困難な重症

1 受付：2020年11月12日 受理：2020年12月14日

2 地方独立行政法人東京都立産業技術研究センター

Tokyo Metropolitan Industrial Technology Research Institute

3 東京都立大学健康福祉学部

Faculty of Health Sciences, Tokyo Metropolitan University
の脳性麻痺児に対して，Hart Walkerと呼ばれる立位姿 勢を保持できる歩行器を利用した場合，立位時間および 足踏み活動が増えると，腸機能が改善することを明らか にしている，また，脳性麻痺児を対象として，歩行器を 含む移動支援機器の自宅, 学校および屋外における利用 状況調査3,4)も行われている. 一方，日本国内においては， 杖や車椅子と比較すれば，街中で歩行器を目にする機会 はほとんどない。歩行器は独歩獲得や歩行訓練，あるい は，活動を通じての身体機能維持を目的として，病院や 肢体不自由特別支援学校などの施設内で利用される状況 にある。

国内に打いて歩行器の利用が少ない事情には, 日本特 有の生活環境に対して, 歩行器の仕様や機能が適合して いないことが考えられる。これを明確化するために，著 者らは全国計357校の小中高肢体不自由特別支援学校の 校長宛，計 480 施設の発達支援センターおよび全国療育 センターのセンター長宛, 重症心身障害理学療法研究会 
会員307名，さらに，小児の保護者に対して，アンケー トを用いた歩行器の利用実態調查を行い，その分析結 果を報告5) した。 理学療法士や作業療法士, 特別支援学 校教諭などの専門家 436 名と保護者 80 名の回答から，小 児の年齢，身体特性，疾患打よびGross Motor Function Classification System ${ }^{6}$ (以下, GMFCS) と呼ばれる脳性 麻痺児の運動能力レベル（屋内外に打いて歩行可能なレ ベル I から，自力移動が不可能な重症のレベル V までの 5つのレベル分類) などの基礎情報を取得し，また，現 在利用中の歩行器の種類, 問題点 - 改善要望などを明確 化した.

上記の調査結果において示された種々の問題点 - 改善 要望の中から，本研究では，専門家の $41 \%$, 保護者の $28 \%$ が指摘した歩行器の操作性について着目した. 現在 普及している市販歩行器においては, 歩行中の安定性や 安全性を高めるため，前輪の旋回防止や後輪の後方回転 防止など，操作機能に制限が設けられている。このため， 方向転換あるいはカーブの際には車体を持ち上げて旋回 させる必要があり，転倒の原因となることもある，狭い 廊下や入り口などがある屋内利用はもとより，砂地や未 舗装道路などの不整地，段差や溝などの障害物の多い屋 外利用では, 歩行器の操作がより一層困難となる。この 問題点に対して，市販歩行器を自主的に改造するような 事例を除けば，解決に至る研究・開発報告は見られない．

そこで本研究では, 脳性麻痺児を対象とし, 方向転換 や段差乗り越えなどの操作性に関わる新しい機構を有す る歩行器を製作した。利用実態調査で得られた結果を踏 まえながら，製品化を意識した仕様を策定し，製作した 歩行器を実証実験により評価した。

\section{2. 歩行器の開発}

\section{2-1. 対象者}

障害者の日常生活及び社会生活を総合的に支援するた めの法律（障害者総合支援法）によれば18歳未満を障害 児と定義しており，運動能力レベルの異なる全年齢児に 対応できる歩行器の開発は困難である。このため, 対象 者を絞ることとした，年齢は歩行器を使用し始める3歳 から9歳程度とした。身体発育が著しい9歳以降の小児に ついては，市販歩行器と同様，各年齢層に適合した大き さの異なる歩行器で対応することを想定した．利用実態 調查の保護者回答に打ける小児の年齢と身長，打よび， 体重の関係から推定される対象小児の身長範囲は $90 \mathrm{~cm}$ から $130 \mathrm{~cm}$ ，体重範囲は $10 \mathrm{~kg}$ から $25 \mathrm{~kg}$ となる。また，
対象とする運動能力レベルは，歩行補助具を用いれば, 屋内外に打いて平坦な場所を歩行可能なGMFCSレベル IIIを主とし，その他，平坦な場所ならば，屋内屋外を問 わず歩行可能なGMFCSレベル II とした.

\section{2-2. 歩行器の基本構造と操作工程}

利用実態調查の保護者回答によれば，GMFCSレベル IIIの小児の $70 \%$ が，Wilson ${ }^{7)}$ が考案したPosture Control Walker（PCW）と呼ばれる歩行器を使用している，ここ で図1にPCWの使用中の様子を示す，身体の後ろ側で支 持し，使用者が引っ張って移動する後方型歩行器の一種 であるPCWは，購入時の公的助成8) の対象であることか ら，実質的な標準歩行器となっている．前方型歩行器と 比較し，後方型歩行器を使用する利点については多数の 報告1,9) があり，例えば，体幹の前傾の抑制，両脚支持時 間の減少などが示されている。本研究で開発する歩行器 も後方型とし，PCWを比較対照器と定めた。

PCW使用時の方向転換には，車体を持ち上げ，旋回 する動作を数回繰り返す必要がある。これに対して，開 発する歩行器は前輪，中央輪，および，旋回操作時のみ 補助的に使用する後輪の6輪で構成され，図2（a）から （c）に示す操作工程を経て方向を転換する．罒2（a）に 示すように，通常の歩行時には，他の市販歩行器と同様,

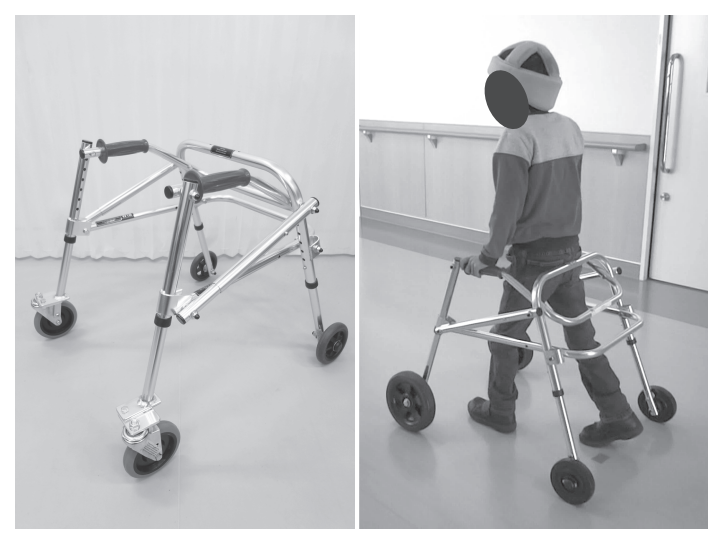

図1 PCWおよびその使用状沉

Fig. 1 Posture Control Walker and its use situation.

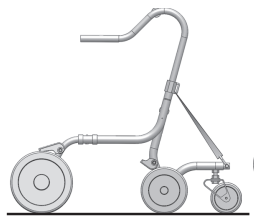

（a）通常状態

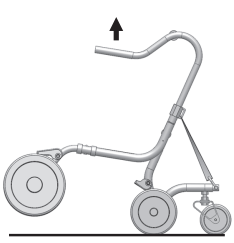

(b) 前輪浮上

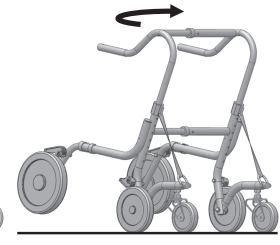

(c) 車体旋回
図2 開発器の方向転換操作

Fig. 2 Schematics of the turning operation of the proposed walker.

実践報告 : 脳性麻痺児を対象とした歩行器の開発 
小児を前輪と中央輪の 4 輪で支えながら前進する．方向 転換や段差乗り越え時には，罒2（b）に示すように，車 体を持ち上げるのではなく，前輪のみを浮上させる。 こ の際，小児が後方に転倒するのを防ぐため，中央輪と後 輪の4輪で支える，その後，図2 (c) に示すように，後方 回転できない左右どちらかの中央輪を中心として車体を 旋回する. 旋回後はハンドルを下し, 前輪を地面に着地 させる.

\section{2-3. 歩行器の製作}

図3（a）に製作した歩行器（以後，開発器と記す）を 示す.フレームの材料には, 軽量性，曲げ加工性，および, 溶接性を考慮し，直径 $25 \mathrm{~mm}$ 打よび $20 \mathrm{~mm}$ ，肉厚 $2 \mathrm{~mm}$ の アルミニウム合金パイプ（A5052TD-H34）を用いた。 フ レームの伸縮が必要な調節部は，両パイプの所定部分に $6 \mathrm{~mm}$ 径の穴を設け，固定ピンを差し込むことで固定した。 その他の接続部分は全て溶接にて完全に固定した。

表 1 に開発器の各所寸法，質量を示す，表には参考 のため，実証実験においても使用したPCW（W1BSX， KAYE Products製) のそれらも併せて示す。表に示す ように，全体寸法・質量に関しては両歩行器で大きな 違いは見られない。開発器の前輪は直径 $200 \mathrm{~mm}$ の固定 輪，中央輪は直径 $150 \mathrm{~mm}$ の固定輪，および，後輪は直径 $100 \mathrm{~mm}$ の旋回輪である. 楔形のブレーキ部品が中央輪に 接触するように取り付けられており，市販歩行器と同様， 後方には回転できない，後輪は上方に $30 \mathrm{~mm}$ 可動するが，

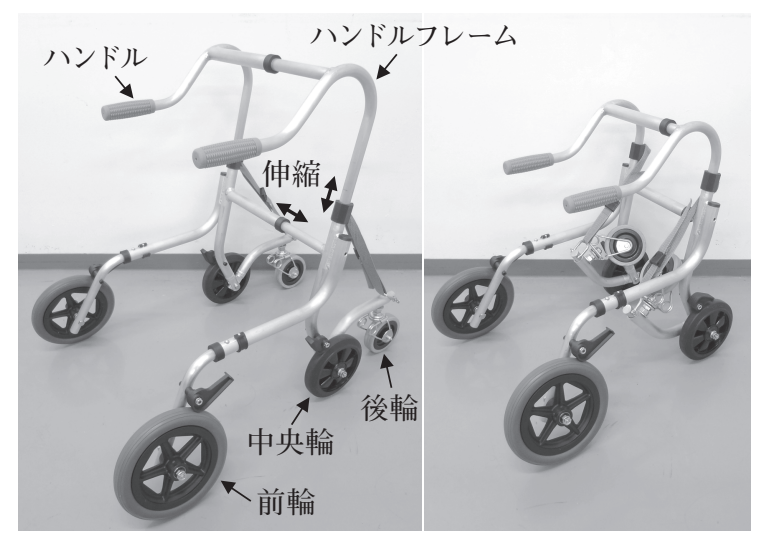

(a) 使用時の状態

（b）収納時の状態
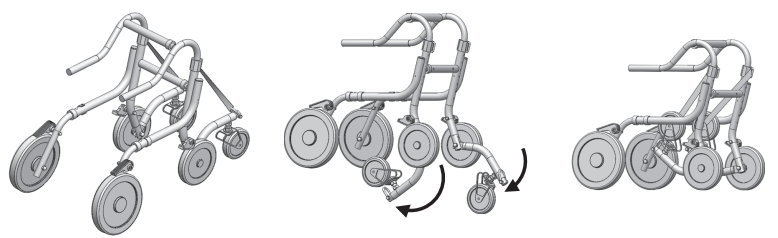

(c) 高さ・幅収縮

(e) ベルト固定

図3開発器とその最小化工程

Fig. 3 Our proposed walker and its minimize process.

表1 開発器とPCWの特性

Tab. 1 Characteristics of the proposed walker and Posture Control Walker.

\begin{tabular}{lcc}
\hline & 開発器 & PCW (W1BSX) \\
\hline 全幅 $[\mathrm{mm}]$ & 580 & 600 \\
\hline 全長 $[\mathrm{mm}]$ & 740 & 780 \\
\hline 高さ $[\mathrm{mm}]$ & 660 & 580 \\
\hline ハンドル高さ $[\mathrm{mm}]$ & $430 \sim 570$ & $420 \sim 560$ \\
\hline ハンドル間幅 $[\mathrm{mm}]$ & 350 & 340 \\
\hline 質量 $[\mathrm{kg}]$ & 5.2 & 4.8 \\
\hline
\end{tabular}

下方にはベルト固定により動かない，ハンドルの高さは 小児の体格に合わせて，固定ピンを抜き差しすることで， $430 \mathrm{~mm}$ から $570 \mathrm{~mm}$ まで7段階で調節できる。 ハンドルと 前輪はフレームで連結されて打り，中央輪を支点として 一体となって可動する．支持基底面が狭くなるものの, 中央輪を小児の足元後方付近に配置したことで，ハンド ルを引き上げ，前輪を浮上させやすい機構とした。 なお， 前輪の最大浮上高さは，安全のため $60 \mathrm{~mm}$ とした.

歩行器の機能に直接関係しないが，車体には曲線を入 れた柔らかみのあるデザインを意識した。 また，不使用 時には幅を狭め，後輪を前方に収納できる機構とし，歩 行器を小さくして収納したいという保護者の要望に応え る工夫を加えた。図3（b）に収納時の開発器の様子を示 す。また，図3（c）から（e)に収納状態に至るまでの状 況図を併せて示す。

\section{2-4. 繰り返し荷重に対する安全性確認}

歩行中，小児からハンドルに荷重が繰り返し加えられ る. 特に, 開発器のハンドルフレームは片持ちの曲がり 梁構造である。このため, その固定端である伸縮調節部 で曲げ応力が最大となり，使用中に破壊する可能性があ る。そこで，実証実験の前に，開発器の繰り返し荷重に 対する安全性を確認した。

四4に，繰り返し荷重試験の状況を示す，図に示すよ うに，左右のハンドル間を鉄鋼製の治具で繋ぎ，この治 具を介することで，両ハンドルの先端から手幅に相当す

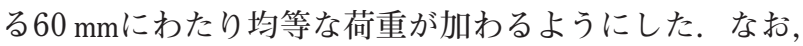
開発器は最も不利な状態（ハンドル高さ：570 mm）で設 置した。繰り返し負荷には，リニアモータ式疲労試験機 (ElectroPuls E10000：INSTRON製）を用いた。試験は 荷重制御で行い，波形を正弦波，周波数を $2 \mathrm{~Hz}$ ，荷重比 （最大繰り返し荷重に対する最小繰り返し荷重の比率）を 0.1とし，100万回の繰り返しを限度とした.

最大繰り返し荷重が，9歳児の体重を想定した $250 \mathrm{Nで}$ ある場合，100万回繰り返した場合に扔いても破壊しな 


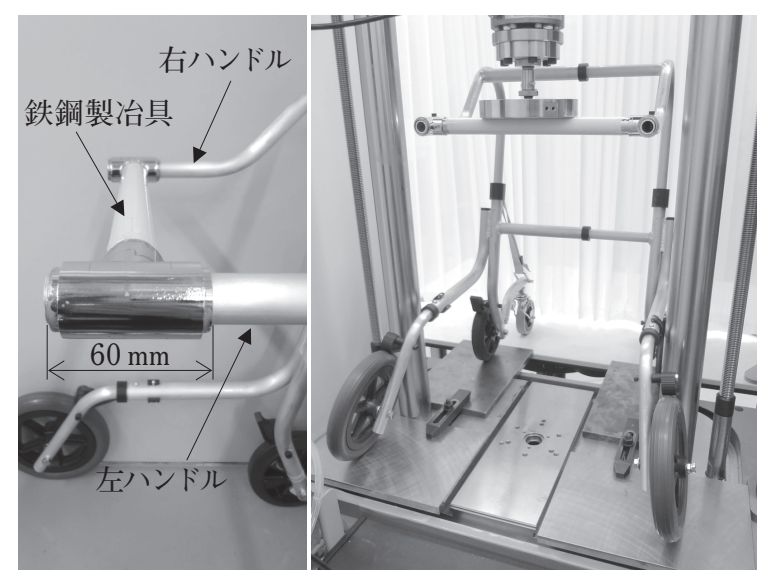

図4 繰り返し荷重試験の状況

Fig. 4 The cyclic loading test.

かった．最大繰り返し荷重を $450 \mathrm{~N}$ まで高めると， 6.26 $\times 10^{5}$ 回でハンドルフレームの固定端, 特に, 固定ピン を差し込む穴で破壊が生じた。歩行中，小児の足は着地 しているため，ハンドルに体重分の荷重が加わることは ない，一方で，衝撃力など，それ以上の荷重が瞬間的に 加わることも想定される. 歩行器を長期使用することを 考えると，上記の結果は安全性を保証できるものではな い.しかし，適時，変形や破壊の有無を目視確認すれば, 実証実験で開発器を使用することは十分可能であると判 断した.

\section{3. 実証実験}

\section{3-1. 実験参加者}

実験参加者は男児3名, 女児5名の計8名 (6歳から10歳) で，全員が脳性麻痺児であった。表 2 に参加した小児の 性別，年齢，GMFCS，および，実験中における装具使 用の有無を示す。実験に先立ち各参加者および保護者に 対して研究概要を口頭にて十分に説明を行い，保護者に よる同意書への署名により実験参加への同意を確認した。 な打，本実験は地方独立行政法人東京都立産業技術研究 センター事業倫理審査委員会人間工学分科会 (承認番号 ES2019-17）打よび東京都立大学荒川キャンパス研究安 全倫理委員会（承認番号19047）の承認を得て実施した.

\section{3-2. 実験手順}

開発器とPCW（W1BSX）の2条件で実験を実施した。 条件を同一にするためPCWの前輪は，標準品とは異なる 直径 $228 \mathrm{~mm}$ の屋外用タイヤ（オプション品）を装着した. 図5に示すように，直線，段差，左右の方向転換の 4 種類
表2 実験参加者の特性

Tab. 2 Characteristics of all participants.

\begin{tabular}{ccccc}
\hline ID & 性別 & 年齢[歳] & GMFCS & 短下肢装具 \\
\hline 1 & 男 & 8 & II & 有 \\
\hline 2 & 女 & 6 & II & 有 \\
\hline 3 & 女 & 9 & III & 有 \\
\hline 4 & 男 & 9 & III & 無 \\
\hline 5 & 男 & 9 & III & 無 \\
\hline 6 & 女 & 9 & III & 有 \\
\hline 7 & 女 & 10 & III & 有 \\
\hline 8 & 女 & 7 & IV & 有 \\
\hline
\end{tabular}

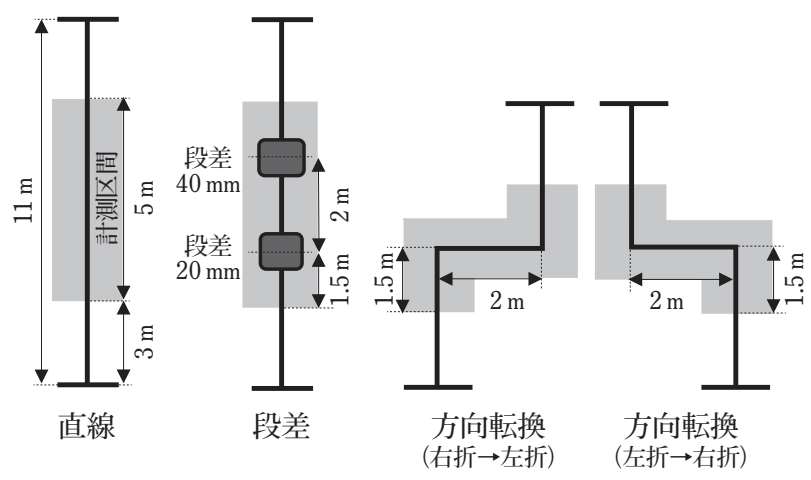

図5 実験課題（左：直線歩行，中央：段差歩行，右：方向 転換歩行）

Fig. 5 Experimental tasks (left: the walking straight task; center: the step task; right: the turn task).

の歩行路を設定した．方向転換歩行路においては，利き 手・利き足や麻痺肢の違いによる得手・不得手を考慮し， 右折後に左折，および，左折後に右折する2種を設定し た. 各歩行路の全長は $11 \mathrm{~m}$ であり，中央 $5 \mathrm{~m}$ を計測区間（前 後3 mは補助路）とした。各歩行路を快適速度で2回歩行 し，計測区間における歩行所要時間をストップウォッチ で計測した．2回の計測結果のうち，速い方の結果を代 表值とした。本実験では，実験参加者の実利用場面を想 定し，開発器の機能により操作がごの程度効率的に行わ れるかを評価することが重要と考え，その客観量として 歩行所要時間を評価パラメータとして選択した。計測機 器の装着などによる実験参加者への負担も考慮した。な お，開発器については，実験前に5分から10分程度の事 前練習を行った。ここでは，前輪だけを浮上させること で方向転換が容易になるという開発器の特性や具体的な 操作方法の説明は行わなかった。また，実験中は安全確 保のため理学療法士が常に小児に寄り添いながら，観察 的に動作分析を行った。実施場所は，神奈川県立保健福 祉大学，筑波大学附属桐が丘特別支援学校，まちだ丘の 上病院であった。 


\section{3-3. 結果と考察}

2名の女児（ID 6 およびID 7）は，体格が開発器に適 合せず，また，7歳女児（ID 8) は，運動能力レベルが GMFCSレベル IV (歩行補助具を利用しても，自力での 歩行は限られ，移動は主に車椅子や電動車椅子で実施） であり，自身でPCWを使用して歩けないことから，安 全のため実験を中止した。このため，男児3名，女児2名 の試技を計測した. 5名の小児は普段から歩行器として PCWを使用，あるいは，使用した経験がある。

表3に開発器使用時の各歩行路における歩行所要時間 を，表4にPCW使用時の歩行所要時間をそれぞれ示す。 計測できた実験参加者数が5名と少なく, 統計分析によ り有意差を示すほどの結果は得られていない。 そこで, 各実験参加者で各歩行器使用時における歩行所要時間の 単純比較の及実施した。 図6にPCW使用時の歩行所要時 間から開発器使用時の歩行所要時間を減じた差分値を示 す. 図中の差分値が正の場合は, 開発器使用により歩行 所要時間が短縮したことを意味する.

直線歩行路では，開発器使用による明確な時間短縮は 確認できなかった，操作に慣れたPCWとは異なり，慣れ ていない開発器では, 若干の恐怖心が生じるためか, 慎 重に操作していた。それでも特段の時間増大は見られな いことから, 開発器の特徵である前輪を浮上させる機構 が寄与しない直線歩行に対してはPCWと同等の機能を

表3 開発器使用時における歩行所要時間

Tab. 3 Walking time (proposed walker).

\begin{tabular}{ccccc}
\hline ID & $\begin{array}{c}\text { 直線 } \\
{[\mathrm{sec} .]}\end{array}$ & $\begin{array}{c}\text { 段差 } \\
{[\mathrm{sec} .]}\end{array}$ & $\begin{array}{c}\text { 方向転換 } \\
\text { (右折 } \rightarrow \text { 左折) } \\
{[\mathrm{sec} .]}\end{array}$ & $\begin{array}{c}\text { 方向転換 } \\
\text { (左折 } \rightarrow \text { 右折) } \\
{[\mathrm{sec} .]}\end{array}$ \\
\hline 1 & 4.28 & 6.76 & 9.35 & 7.80 \\
\hline 2 & 6.90 & 8.16 & 6.20 & 6.31 \\
\hline 3 & 6.68 & 17.8 & 11.7 & 6.56 \\
\hline 4 & 8.70 & 17.8 & 16.0 & 18.8 \\
\hline 5 & 5.40 & 8.50 & 7.80 & 8.70 \\
\hline
\end{tabular}

表4 PCW使用時における歩行所要時間

Tab. 4 Walking time (Posture Control Walker).

\begin{tabular}{ccccc}
\hline ID & $\begin{array}{c}\text { 直線 } \\
{[\mathrm{sec} .]}\end{array}$ & $\begin{array}{c}\text { 段差 } \\
{[\mathrm{sec} .]}\end{array}$ & $\begin{array}{c}\text { 方向転換 } \\
\text { (右折 } \rightarrow \text { 左折) } \\
{[\mathrm{sec} \text {. }]}\end{array}$ & $\begin{array}{c}\text { 方向転換 } \\
\text { (左折 } \rightarrow \text { 右折) } \\
{[\mathrm{sec} .]}\end{array}$ \\
\hline 1 & 4.72 & 4.95 & 8.60 & 6.01 \\
\hline 2 & 6.91 & 9.21 & 5.80 & 6.79 \\
\hline 3 & 3.10 & 17.3 & 8.14 & 15.6 \\
\hline 4 & 7.50 & 20.9 & 25.9 & 17.3 \\
\hline 5 & 7.00 & 13.2 & 10.0 & 7.70 \\
\hline
\end{tabular}

有していることが確認された。 なお，歩行所要時間が長 くなった9歳女児（ID 3) は，GMFCSレべル II の2児（ID 1，2）および装具の装着がない2名の男児（ID 4，5）と 比較し，図7に示すように，中央輪が取り付けられたフ レームに下腿部や補装具を衝突させる機会が多く観察さ れた。左右フレーム間の幅が $350 \mathrm{~mm}$ (PCWでは最も広 い部分で $450 \mathrm{~mm}$ ）と狭く，加えて，この女児は臨床的に 股関節の内旋が認められて抢り，歩行時に足が外側に振 り出されることに起因すると考えられる．各小児とも開 発器の使用で歩行が不安定になることはなかったが，左 右フレーム間の幅を適時調整できる機構の導入は検討の 余地がある.

段差歩行路では3児（ID 2，4，5）において，開発器 使用による時間短縮が確認された。両歩行器の前輪は直 径 $200 \mathrm{~mm}$ 以上と大きく，高さ $20 \mathrm{~mm}$ の段差は乗り越える ことができた。なお，段差 $20 \mathrm{~mm}$ は車道等に対して横断 歩道に接続する歩道等の部分の縁端の高さ10) に相当す る. 一方，高さ $40 \mathrm{~mm}$ の段差では，段差到達後に一旦停

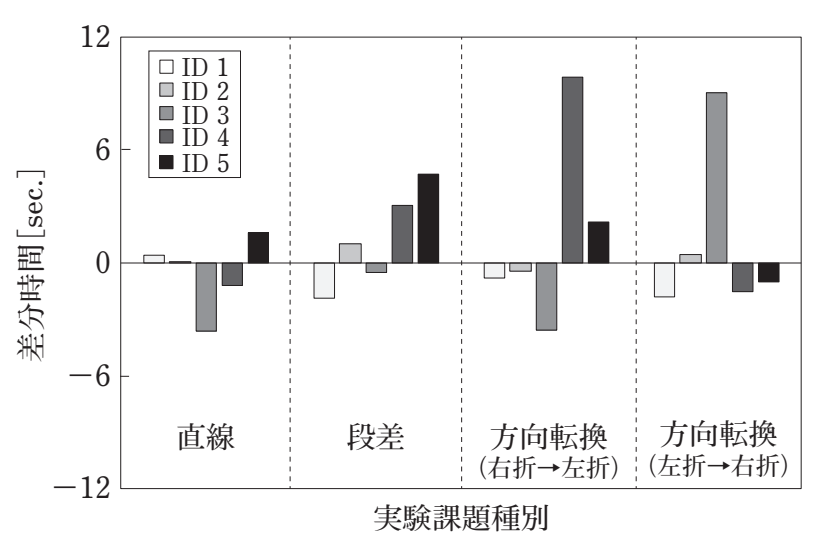

図6 歩行所要時間の差分值

Fig. 6 Differences in walking times between proposed walker and Posture Control Walker.

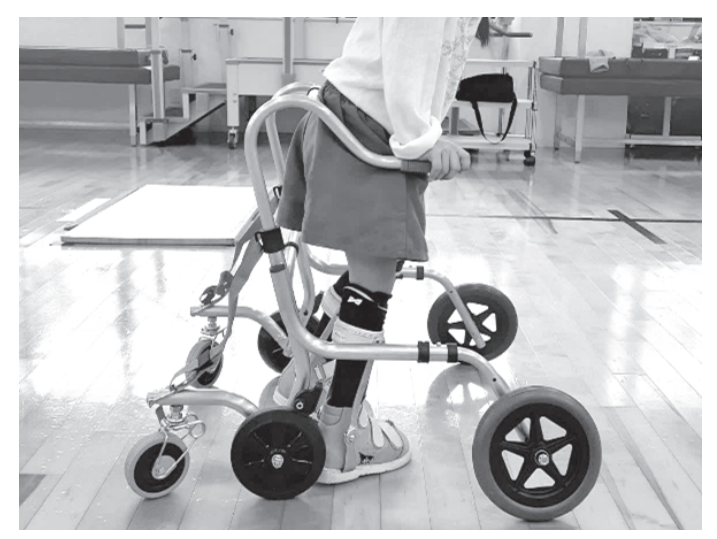

図7開発器使用での問題点

Fig. 7 Problems of the proposed walker in use. 
止し, 歩行器の前輪を浮上させる必要があった.この動 作に打いて, 開発器の機構が有効に機能したと考えられ る. 実証実験ではPCWには直径 $228 \mathrm{~mm}$ 前輪を装着し たが，標準仕様では直径 $127 \mathrm{~mm}$ 前輪が装着されている. この場合，例え低い段差であっても乗り越えにくいこと が，利用実態調査より明らかとなっている。開発器では 直径 $200 \mathrm{~mm}$ の前輪を標準としている．また，前輪を浮上 させやすい機構が段差乗り越えに適していると考えられ， 開発器の設計意図の通り PCWより優位な操作機能を有 していることが確認された。なお，8歳男児（ID 1) にお いて開発器使用により歩行所要時間が長くなったのは, 途中で一度，足が中央輪に衝突したことで歩行速度が落 ちたことが原因であり，その他の動作に問題は観察され なかった。また，9歳女児（ID 3) に打いては0.5秒差と いうこともあり，明確な理由を見出すに至らなかった。

2種類の方向転換歩行路では，事前に想定した利き手． 利き足や得手 - 不得手を反映して, どちらか一方の歩行 路において4览（ID 2，3，4，5）で開発器使用による時 間短縮が見られた。特に9歳女児（ID 3) と9歳男児（ID 4）は9秒以上の短縮となった. PCWの使用時には，車 体を持ち上げ，旋回する動作を数回繰り返すことで，方 向転換を行う必要があった。一方, 開発器を使用した場 合，図8（a）から（d）に示すように，ハンドルを引き上 げ，前輪を浮上させた後に車体を旋回させる，一連の方 向転換操作を確認した。この操作が達成されれば，歩行 所要時間を大幅に短縮できる可能性が示唆された。なお， 8歳男児（ID 1）は5児の中で唯一，両方向転換歩行路と もに開発器使用により歩行所要時間が長くなった。この 男児は立位が安定しており，PCW使用時には，車体を 持ち上げた後，一度で直角に旋回していた。開発器使用 時でも同様の操作を行ったが，機構や質量バランスの影 響のためか，車体を直角以上に旋回してしまい，方向修 正するまでの時間を余分に要していた。

前節に記したように，実駼前に5分から10分程度の事 前練習を行ったが，前輪だけを浮上させることで方向転 換が容易になるという開発器の特性や具体的な操作方法 の説明は行わなかった。それにも関わらず，自然と設計 意図の通りの操作を行う複数の小児が観察された。この ことからも，操作性向上を目的とした設計・開発方針の 妥当性が確認された。しかし一方で, 例え同じ小児であっ ても，普段から乗り慣れているPCWと同様に，開発器全 体を持ち上げて方向転換を行う様子も観察された。 今後 の実証実験では，事前練習に十分な時間を割き，開発器 の特徵や操作方法，それに伴う身体，特に，前傾姿勢の 状態から身体重心を後方移動させる仕方などを理解した

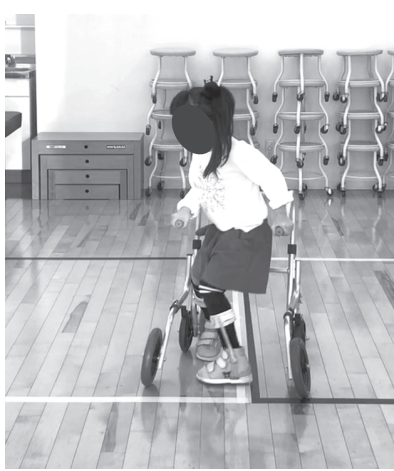

（a）通常状態

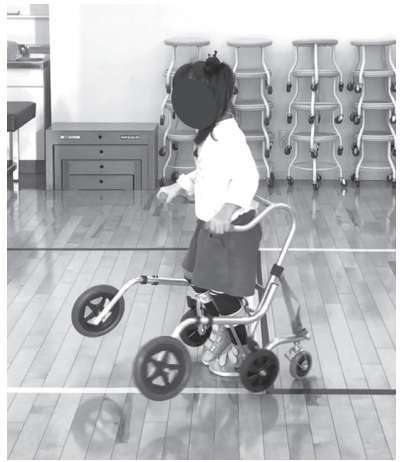

(c) 車体旋回

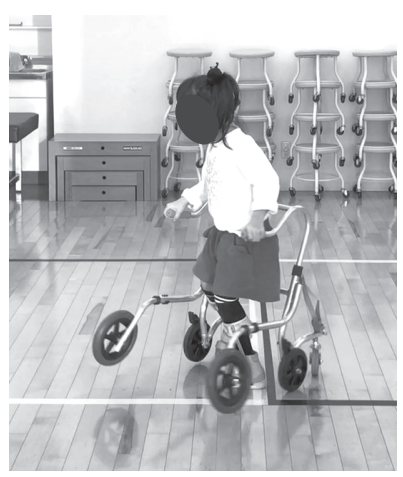

(b) 前輪浮上

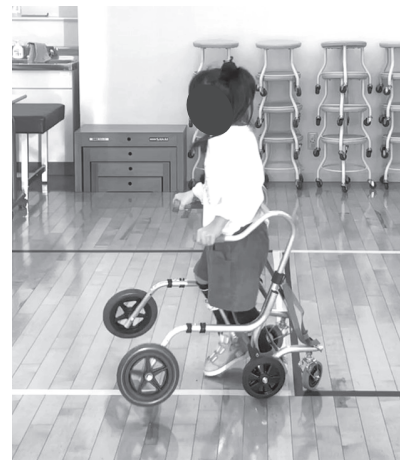

（d）前輪着地
図8 方向転換操作

Fig. 8 Turning operation process of the proposed walker.

上で, 安心して実験に望めるような工夫が必要といえる.

\section{4. おわりに}

本研究では，年齢が3歳から9歳程度であり，運動能力 レベルが主にGMFCSレベル III の脳性麻痺児を対象とし， 方向転換や段差乗り越えなどの操作性に関わる新しい機 構を有する歩行器を開発した。

開発した歩行器は後方型歩行器に分類され, 前輪, 中 央輪，および，後輪の6輪で構成された，実証実験では， 開発した歩行器と市販歩行器の1つである $\mathrm{PCW}$ 用いて, 直線歩行, 高さ $20 \mathrm{~mm}$ 抢よび $40 \mathrm{~mm}$ の段差乗り越え, 左折 · 右折の順序が異なる 2 種類の方向転換を行う 4 種類の歩行 路の快適速度における歩行所要時間を計測した。実験に は8名の脳性麻痺児が参加し，最終的に，男児3名および 女児2名のデータを得た。その結果，PCWと比較して開 発した歩行器では，ハンドルを引き上げ，前輪のみを浮 上させ，その後，車体を旋回させるという一連の操作に より，段差乗り越えでは3児，および，方向転換では4児 の歩行所要時間が短縮した。これにより，開発器はPCW より優位な操作機能を有している可能性が示唆された.

今回，実験に参加しながらも計測に至らなかった小児 がいたことから，今後は複数の大きさの歩行器を用意す 
るなどして, 妥当性確認のためのデータをより多く取得 していく。また，実証実験により得られた知見を開発器 の改良・改善に生かし，日本人小児に適した歩行器の提 供による生活の質の向上に貢献したい。

\section{謝 辞}

歩行器の仕様策定および実証実験にご協力頂いた, 国 士舘大学の松浦孝明氏, 神奈川県立保健福祉大学の米津 亮氏, 順天堂大学の松田雅弘氏, 東京工科大学の楠本泰 士氏，埼玉県立小児医療センターの阿部広和氏に深く感 謝致します。

\section{付 記}

本論文の内容の一部は, 日本機械学会福祉工学シンポ ジゥム2019（LIFE2019）において発表した.

\section{文 献}

1) Lynne, L.; Kathleen, B.; et al. Anterior versus posterior walkers: A gait analysis study. Developmental Medicine \& Child Neurology. 1990, 32 (12), p.1044-1048.

2) Eisenberg, S.; Zuk, L.; et al. Contribution of stepping while standing to function and secondary conditions among children with cerebral palsy. Pediatric Physical Therapy. 2009, 21 (1), p.79-85.

3) Lawlor, K.; Mihaylov, S.; et al. A qualitative study of the physical, social and attitudinal environments influencing the participation of children with cerebral palsy in northeast England. Pediatric Rehabilitation. 2006, 9 (3), p.219-228.

4) Palisano R.; Tieman, B.; et al. Effect of environmental setting on mobility methods of children with cerebral palsy. Developmental Medicine \& Child Neurology. 2003, $45(2)$, p.113-120.

5） 大島浩幸, 西川康博, 他. 日本における小児用歩行器の利 用実態調査. 人間工学. 2019, 55 (5), p.180-188.

6) Palisano, R.; Rosenbaum, P.; et al. Development and reliability of a system to classify gross motor function in children with cerebral palsy. Developmental Medicine \&
Child Neurology. 1997, 39 (4), p.214-223.

7) Wilson, J. Selecting and using posture walkers for children with cerebral palsy. Totline. 1988, 14, p.15-16.

8）厚生労働省. “補装具費支給制度の概要”. https://www. mhlw.go.jp/stf/seisakunitsuite/bunya/hukushi_kaigo/ shougaishahukushi/yogu/aiyo.html, (参照 2020-11-3)

9) Poole, M., Simkiss, D.; et al. Anterior or posterior walkers for children with cerebral palsy? A systematic review. Disability and Rehabilitation: Assistive Technology. 2018, 13 (4), p.422-433.

10）国土交通省. “移動等円滑化のために必要な道路の構 造に関する基準を定める省令”. https://www.mlit.go.jp/ sogoseisaku/barrierfree/content/001341214.pdf，（参照 2020-11-3)

\section{著者情報}

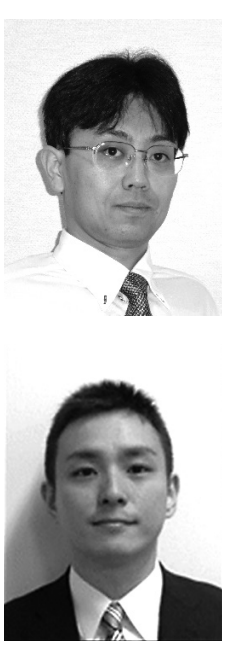

西川康博（にしかわやすひろ）

2005年同志社大学大学院工学研究科機械 工学専攻博士後期課程修了. 博士 (工学). 日本機械学会の会員. 2006年から千葉県 産業支援技術研究所研究員. 2009年から 現職.

連絡先：nishikawa.yasuhiro@iri-tokyo.jp

大島浩幸（おおしまひろゆき, 正会員, 連 絡著者)

2012年北海道大学大学院教育学院博士後 期課程修了. 博士 (教育学). 筑波大学シ ステム情報系研究員を経て，2014年10月 から現職. 日本人間工学会の会員. 日本ス ポーツ協会公認スポーツ指導員, 日本障が い者スポーツ協会公認中級障がい者スポー ツ指導員.

連絡先：ohshima.hiroyuki@iri-tokyo.jp

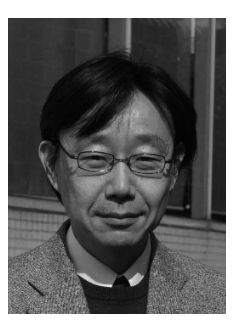

新田收（にったおさむ）

1997年日本大学大学院理工学研究科医療. 福祉工学博士後期課程修了. 博士 (工学). 理学療法士. 東京都立大学健康福祉学部, 教授. 日本理学療法士協会, 日本支援工学 理学療法士学会, 日本リハビリテーション 医学会の会員.

連絡先：nittaosm@tmu.ac.jp 